\title{
THE ROLE AND CHALLENGES OF ISLAMIC EDUCATION IN INDONESIA IN THE DISRUPTIVE ERA: THE ANALYSIS OF THE SYSTEM OF ISLAMIC EDUCATION CHARACTER IN INDONESIA
}

\author{
Imam Syafi'i \\ Institut Ilmu Al-Qur'an (IIQ) \\ Ciputat, Tangerang Selatan, Banten, Indonesia, 15419 \\ E-mail: isa.tamyes@gmail.com \\ Syaifulloh Yusuf \\ Universitas Islam Indonesia \\ Ngaglik, Sleman, Yogyakarta, Indonesia, 55584 \\ E-mail: syaifulloh.yusuf@uii.ac.id
}

\begin{tabular}{c|c|c}
\hline Received: & Revised: & Approved: \\
12/05/2021 & $21 / 06 / 2021$ & $24 / 06 / 2021$ \\
\hline
\end{tabular}

DOI : https://doi.org/10.32332/akademika.v26i1.3285

\begin{abstract}
The Role and Challenges of Islamic Education in Indonesia in the Disruptive Era: The Analysis of the System of Islamic Education Character in Indonesia Licensed Under a

Creative Commons Attribution-ShareAlike 4.0 International License
\end{abstract}

\begin{abstract}
Various types of character education theories have swiftly developed, such as Thomas Lickona's notion of moral knowing, moral emotion, and moral deeds. The Presidential Regulation No. 87 of 2017 on Strengthening of Character Education has also spawned a slew of derivative theories. Some of the new results in character education are holistic-integrative and character-interconnected. However, character education, particularly Islamic education, continues to be a source of concern for all parties. The challenges of Islamic education are increasing with the sophistication of technology. The community's faltering use of technology is a major impediment to increasing Islamic education's principles. This study's research technique is descriptive-qualitative, utilizing literature reviews from a variety of scientific data sources. According to the findings and conclusions of this study, Islamic education in Indonesia plays both a function and a challenge in the age of disruption. Problems in the sphere of educational technology, the dichotomy of science, educational evaluation, subject matter delivery, and geographical challenges of Islamic education are among the challenges in Islamic education. Thus, to create a golden generation of Indonesia in 2045, Islamic education plays an important role in maintaining Islamic values, character values and noble character.
\end{abstract}

Keywords: Role, Challenges, Islamic Education, Educational Technology

\section{A. Introduction}

The situation of Islamic education in the twenty-first century is one of a modern period of Islamic education with many roles and challenges. Materials and teaching 
methods are rapidly evolving. For contemporary Islamic education, technological sophistication is a challenge. Meanwhile, some individuals are unprepared to accept the fact. The impact of Islamic education on influencing people's views toward technology is significant. The teaching of Islamic education, for example, will contribute to the development of student's character.

The National Mental Revolution Movement is one of the government's initiatives to overcome the challenges of educational technology (GNRM). The goal of mental revolution is to change students' views to shape their character. Islamic education helps society thrive in the fields of industry ${ }^{1}$, economic philosophy ${ }^{2}$, field practice, pedagogical instruction, and general knowledge by shaping students' personalities ${ }^{3}$ from an early age. 4 The issue is that achieving the aim of enhancing character education by 2045 to generate a golden generation ${ }^{5}$ would need significant effort in several of these areas.

Sexual deviation, theft, criminal acts, brawls, muggings, drug abuse, and other examples of disgraceful attitudes shown by a number of education students have caused many critics to the world of education today. The cause for this attitude is that education is currently focused solely on academic intelligence, rather than balancing it with emotional intelligence ${ }^{6}$. As a result, Islamic education may be used as a valuable resource for developing a respectable attitude and developing excellent character. The most significant challenge is the sophistication of instructional technology and its under-utilized potential.

\section{B. Learning Material and Methods}

Social identity is an important thing that must be considered. The attitude of the community in facing the era of educational technology becomes the basis for academic anxiety to determine Islamic education policies. The success of educational institutions in producing excellent graduates is determined by their materials and techniques. Learning facilities in formal, informal, and non-formal institutions must be prepared as well as possible. School administrators, boarding school supervisors, and other educational institution leaders must be competent to develop blended learning

1 Fathur Rokhman et al., “Character Education for Golden Generation 2045 (National Character Building for Indonesian Golden Years)," Procedia - Social and Behavioral Sciences 141, 4th World Conference on Learning Teaching and Educational Leadership (WCLTA-2013) (August 25, 2014): 1161.

2 Ladda Silanoi, "The Development of Teaching Pattern for Promoting the Building up of Character Education Based on Sufficiency Economy Philosophy in Thailand," Procedia - Social and Behavioral Sciences 69, International Conference on Education \& Educational Psychology (ICEEPSY 2012) (December 24, 2012): 1812.

3 Mehmet Ülger, Süleyman Yiğittir, and Orhan Ercan, "Secondary School Teachers' Beliefs on Character Education Competency," Procedia - Social and Behavioral Sciences 131, 3rd World Conference on Educational Technology Researches 2013, WCETR 2013, 7-9 November 2013, Antalya, Turkey (May 15, 2014): 442.

4 Chou Mei-Ju, Yang Chen-Hsin, and Huang Pin-Chen, "The Beauty of Character Education on Preschool Children's Parent-Child Relationship," Procedia - Social and Behavioral Sciences 143, 3rd Cyprus International Conference on Educational Research, CY-ICER 2014, 30 January - 1 February 2014, Lefkosa, North Cyprus (August 14, 2014): 527.

“Perpres_Nomor_87_Tahun_2017.Pdf," n.d., 4, accessed May 7, 2021, https://setkab.go.id/wp-content/uploads/2017/09/Perpres_Nomor_87_Tahun_2017.pdf.

6 Nur Hidayat, "Peran dan Tantangan Pendidikan Agama Islam di Era Global," EL TARBAWI 8, no. 2 (2015): 144. 
models?.

Materials and methods merge into a single entity that is impossible to separate. Students are not entirely in regular circumstances, but the diversity of students must also be taken into account. There are undoubtedly students with special needs in Indonesia and other nations. Online distance learning can help us enhance our technological skills. However, there are limitations such as a lack of social contact, the content presented, the technology employed, the distribution methods and the assessment tools used ${ }^{8}$.

A survey of 5,000 Chinese students found that online learning is utilized to expand knowledge in a favorable method to cope with it. If students see the covid-19 pandemic positively, then online learning using various methods has a highly favorable influence 9 . As a developing country, Indonesia must use technology as a learning tool. Materials and procedures are tailored to the needs of educational establishments. As boarding-based Islamic educational institutions, Islamic boarding schools must be able to make significant technological improvements.

It's noteworthy to note that not everyone agrees or has the same view when it comes to online teaching and learning. Age, independence, personal attitude, community character, and other factors must all be considered. One British researcher sought to assess lecturers' and students' experiences and perceptions of using social media in teaching and learning. There are three major themes: personal (experience and attitude), pedagogy (learning material demands), and institutional (institutional encouragement $)^{10}$. These three fundamental characteristics may be found in any country, including Indonesia, where government policies encourage and demand. The independent learning (Merdeka Belajar) curriculum is one of the real examples in Indonesia.

\section{Technology and Its Development in Islamic Education}

In Islamic education, technology is a new phenomenon that cannot be avoided. Technology is one of the supporting components in the achievement of high-quality education. Various development strategies and models exist. For example, social media is used in the blended learning method for learning Tahsin Al-Qur'an. Tahsin is a way of studying the Qur'an in which the reading rules reflect a beautiful and exact voice ${ }^{11}$.

7 Yusuf Hanafi et al., "The New Identity of Indonesian Islamic Boarding Schools in the 'New Normal': The Education Leadership Response to COVID-19,' Heliyon 7, no. 3 (March 1, 2021): 2405.

8 Abdallah A. Alshawabkeh, M. Lynn Woolsey, and Faten F. Kharbat, "Using Online Information Technology for Deaf Students during COVID-19: A Closer Look from Experience," Heliyon 7, no. 5 (May 1, 2021): e06915.

${ }^{9}$ Xuefang Xie, Zhipeng Zang, and José M. Ponzoa, “The Information Impact of Network Media, the Psychological Reaction to the COVID-19 Pandemic, and Online Knowledge Acquisition: Evidence from Chinese College Students," Journal of Innovation E Knowledge 5, no. 4 (October 1, 2020): 297.

${ }^{10}$ Alison J. Purvis, Helen M. Rodger, and Sue Beckingham, “Experiences and Perspectives of Social Media in Learning and Teaching in Higher Education," International Journal of Educational Research Open 1 (January 1, 2020): 100018.

11 Muh. Syaiful Romadhon, Amalia Rahmah, and Yekti Wirani, "Blended Learning System Using Social Media for College Student: A Case of Tahsin Education," Procedia Computer Science 161, The Fifth Information Systems International Conference, 23-24 July 2019, Surabaya, Indonesia (January 1, 2019): 160. 
This blended learning system combines two types of learning, namely online and network-based learning. For learning tahsinul Qur'an, all students should learn in a face-to-face format. However, students can now do tahsinul Qur'an online using this technology.

The COVID-19 epidemic has driven every educational institution to adopt an elearning system. Student success has increased as a result of the shift to online learning, particularly in terms of technology utilization ${ }^{12}$. In the field of medical education, technology will play an increasingly significant role in the future ${ }^{13}$, particularly in the health sector, where it may help minimize the danger of disease spread ${ }^{14}$. Online learning, according to medical students at King Abdulaziz University, does not waste time; however, there are some factors to consider, such as training, electronic course design, intensive engagement, high motivation, and integrated learning ${ }^{15}$. The most difficult issue for healthcare students, particularly in the field of practice, is that they must be closely connected.

When the world is confronting the worldwide disaster of Covid-19, education policymakers support e-learning more aggressively. According to a survey of 183 nations, 80 percent of the transfer process in the digital world is influenced by globalization, which has a substantial impact on technology adoption in all emerging nations ${ }^{16}$, In the millennial era, an information technology-based education system has emerged as a new learning method. Distance learning courses with a range of current facilities are facilitated by the policies of general educational institutions and Islamic education in particular. Islamic educational institutions are presently putting more effort into measuring their students' achievement. Making learning products, rather than merely consuming them, is prioritized in Islamic education.

\section{The Age of Islamic Education and Post-Covid 19 Pandemic}

The Indonesian people have not yet recovered from the Covid-19 pandemic. Covid-19 is still available in a variety of forms. Covid-19 variations may be divided into at least four categories ${ }^{17}$. This demonstrates that the start of the "post" covid-19

12 Ahmed Elzainy, Abir El Sadik, and Waleed Al Abdulmonem, "Experience of ELearning and Online Assessment during the COVID-19 Pandemic at the College of Medicine, Qassim University," Journal of Taibah University Medical Sciences 15, no. 6 (December 1, 2020): 456.

13 Noor M. Alqudah et al., "Perception and Experience of Academic Jordanian Ophthalmologists with E-Learning for Undergraduate Course during the COVID-19 Pandemic," Annals of Medicine and Surgery 59 (November 1, 2020): 44.

14 Rajib Shaw, Yong-kyun Kim, and Jinling Hua, "Governance, Technology and Citizen Behavior in Pandemic: Lessons from COVID-19 in East Asia," Progress in Disaster Science 6 (April 1, 2020): 100090.

15 Nahla Khamis Ibrahim et al., "Medical Students' Acceptance and Perceptions of eLearning during the Covid-19 Closure Time in King Abdulaziz University, Jeddah," Journal of Infection and Public Health 14, no. 1 (January 1, 2021): 17.

${ }^{16}$ Marinko Skare and Domingo Riberio Soriano, "How Globalization Is Changing Digital Technology Adoption: An International Perspective," Journal of Innovation E Knowledge (April 22, 2021), accessed May 8, 2021, https://www.sciencedirect.com/science/article/pii/S2444569X21000202.

17 Luthfia Ayu Azanella, "Empat Varian Baru Virus Corona Masuk Indonesia," KOMPAS.com, last modified May 7, 2021, accessed May 9, 2021, https:// www.kompas.com/tren/read/2021/05/07/140000765/empat-varian-baru-viruscorona-masuk-indonesia-di-mana-saja-kasusnya-. 
epidemic cannot be predicted, because the Covid-19 pandemic is still going strong. COVID-19 may be prevented in some methods, including hand washing, using masks, keeping a safe distance, and so on. The government conducts vaccination campaigns to maintain a more flawless immune system.

Islamic education must be ready to face and take a stand during the COVID-19 pandemic and after it happened. The COVID-19 has been shown to have an effect on mental and psychological stress ${ }^{18}$ in some nations, including Indonesia. The readiness of Islamic education has a role in maintaining educational stability. It must assist social groups with poor education, in addition to the effects of psychological pressure ${ }^{19}$. People in Bangladesh frequently experience depression, anxiety, and stress four months following the COVID-19 pandemic ${ }^{20}$, necessitating a rigorous preventive plan. Psychological variables have a significant impact on many aspects of life, including the economy, health, technology, and education. Religion has had a significant part in the formulation, calming, and treatment of the COVID-19 pandemic.

The Covid-19 phenomenon, according to Amin Abdullah, is a stressful event. The conflict between religious and scientific rationality has not been able to communicate effectively. Between religious and scientific actors, there is no place for productive, positive, and constructive communication. Religious leaders want conventions, culture, and traditions to continue as they have in the past. Meanwhile, scientists tend to forget about it all and even abandon a long-standing practice ${ }^{21}$. In post-covid-19 life, this appealing offer is required. To be able to address issues, many disciplines must be integrated, cooperated, and merged.

Talking about Amin Abdullah's multimodal, interdisciplinary, and trans disciplinary knowledge, it is expected at least to give a solution so that it can help individuals from blaming one other, especially in the realm of Islamic education. Scientists and religious experts must think out of the box to connect their respective fields of expertise with the subject of a current issue. If the two have communicated properly, removed subjectivity, and encouraged creative imagination ${ }^{22}$, they can work together in maintaining the difficulties of contemporary life. As a result, post-Covid-19 Islamic education, as a kind of science-religion partnership, is waiting for the larger society to accept it as a viable solution to a global catastrophe problem.

\section{E. The Character of Islamic Education and the Challenge of the Millennial Era}

The millennial, digital, and technological eras have lately been hot issues in modern education, particularly in Islamic education. There are major problems in Islamic education that cannot be ignored. In summary, a character is a must for everyone in the present digital world. The book Washaya al-abaa 'lil abnaa', for example, is one of the research's offerings, and it is appropriate for the contemporary digital era.

18 Abdul Gaffar Khan et al., "Quality of Life in the COVID-19 Outbreak: Influence of Psychological Distress, Government Strategies, Social Distancing, and Emotional Recovery," Heliyon 7, no. 3 (March 1, 2021): e06407.

19 Roy Rillera Marzo et al., "Psychological Distress during Pandemic Covid-19 among Adult General Population: Result across 13 Countries," Clinical Epidemiology and Global Health 10 (April 1, 2021): 100708.

${ }^{20}$ Abdullah Al Zubayer et al., "Psychological States of Bangladeshi People Four Months after the COVID-19 Pandemic: An Online Survey," Heliyon 6, no. 9 (September 1, 2020): e05057.

${ }^{21}$ Muhammad Amin Abdullah, Multidisiplin, Interdisiplin, \& Transdisiplin (Metode Studi Agama \& Studi Islam Di Era Kontemporer), III. (Yogyakarta: IB Pustaka, 2021), 314.

22 Ibid., 323. 
It focuses on morality relating to God (vertically) and morals relating to people (horizontally) ${ }^{23}$. Work ethic, social attitude, moral orientation, internalization of faith, and Islam all benefit from having a religious attitude or character ${ }^{24}$. In reality, academic anxiety enhances the necessity to apply the notion of Ihsan values to every individual25, not only Iman and Islam ${ }^{26}$. As a result, Ihsan becomes a useful instrument for assessing the quality of Islamic education. The disadvantage is that no sophisticated technique exists to detect Ihsan's nature ${ }^{27}$.

Internalization of derived character values that have not been applied is a fresh topic of discussion. The educational idea of $\mathrm{Ki}$ Hajar Dewantara, namely communication between educational institutions, parents, and the environment, must be implemented. Teachers and parents should collaborate to give children with character education guidance ${ }^{28}$. Discipline ${ }^{29}$, faith, responsibility, independence, nationalism, and mutual collaboration, for example, are the driving forces behind family involvement in character education ${ }^{30}$. According to Mariah and Nurbaiti, parents must lead and monitor their children's usage of technology, as well as assess and give learning solutions ${ }^{31}$.

In the field of information technology (IT), there are at least ten quality indicators, one of which is high-speed internet ${ }^{32}$. The pandemic of COVID-19 has accelerated the use of information technology ${ }^{33}$. Each country's policymakers or

23 Syaifulloh Yusuf, "Konsep pendidikan akhlak syeikh muhammad syakir dalam menjawab tantangan pendidikan era digital," TA'DIBUNA: Jurnal Pendidikan Agama Islam 2, no. 1 (May 21, 2019): 1.

24 Sri Haningsih et al., Buku Panduan MKWU Pendidikan Agama Islam Untuk Program Sarjana (S1), I. (Yogyakarta: Universitas Islam Indonesia, 2021), 23, accessed May 11, 2021, https://dspace.uii.ac.id/handle/123456789/27629.

25 Ibid., 122.

26 Muhammad Arif Ihwanto, Anwar Sutoyo, and Sudarmin Sudarmin, "Desain Pendidikan Karakter Berbasis Nilai-Nilai Ihsan Bagi Siswa MI NU Salafiyah Kudus," Innovative Journal of Curriculum and Educational Technology 6, no. 1 (July 22, 2017): 5.

27 Syaifulloh Yusuf and Kurniawan Dwi Saputra, "Ihsan-Based Character Education" (Presented at the 2nd Southeast Asian Academic Forum on Sustainable Development (SEAAFSID 2018), Atlantis Press, 2021), 210, accessed May 10, 2021, https://www.atlantispress.com/proceedings/seaafsid-18/125953604.

28 Sri Astuti et al., "Sinergitas Guru dan Orangtua dalam Integrasi Nilai Karakter pada Pembelajaran Daring di Pandemi Covid-19," Jurnal Pendidikan Karakter 0, no. 1 (April 27, 2021): 1, accessed May 10, 2021, https://journal.uny.ac.id/index.php/jpka/article/view/38898.

29 Syaifulloh Yusuf, Manajemen Peserta Didik Untuk Program Sarjana (S1), I. (Yogyakarta: Universitas Islam Indonesia, 2021), 83, accessed May 11, 2021, https:/ / dspace.uii.ac.id/handle/123456789/27628.

${ }^{30}$ Lailati Nazula and Erni Munastiwi, "Penguatan Karakter Anak dalam Keluarga dalam Situasi Pandemi Covid-19," Jurnal Pendidikan Karakter 0, no. 1 (April 27, 2021): 1, accessed May 10, 2021, https://journal.uny.ac.id/index.php/jpka/article/view/37648.

31 Fajar Fandi Atmaja and Syaifulloh Yusuf, "Model Pendampingan Manajemen Masjid Ramah Anak Dan Aman Covid-19 Di Masjid Al-Musthofa Dusun Jaten, Sendangadi, Mlati, Sleman," Yumary: Jurnal Pengabdian kepada Masyarakat 1, no. 3 (March 29, 2021): 147.

32 Fereydoon Azma, "The Quality Indicators of Information Technology in Higher Education," Procedia - Social and Behavioral Sciences 30, 2nd World Conference on Psychology, Counselling and Guidance - 2011 (January 1, 2011): 2535.

33 Ronan Doyle and Kieran Conboy, "The Role of IS in the Covid-19 Pandemic: A LiquidModern Perspective," International Journal of Information Management 55, Impact of COVID-19 
governments choose their role in utilizing technology. Educational institutions that employ online learning in every course are feeling the effects of the COVID-19 pandemic on their usage of technology ${ }^{34}$. The upside to this forced situation is that everyone is attempting to learn how to use technology. On the other side, a lack of control over the use of technology has tainted the character of Islamic education. Students' broken attitudes and morals become the primary victims of technology.

Indonesia is a multi-ethnic country. Its variety is represented in a wide range of ethnic groups, races, cultures, local wisdom, religions, and other factors. To preserve the Republic of Indonesia's Unitary State, local wisdom, customs, and culture must be unified and wrapped in general character qualities such as noble character, excellent attitude, and good character 35 . As in the national figure RA Kartini, who possesses at least five characteristics, including unyielding/unafraid of failure, high literacy, and brave to be honest, tolerant, and religious ${ }^{36}$. As a result, it is reasonable that the President of the Republic of Indonesia issued Regulation No. 87 of 2017 on the strengthening of character education (PPK). The regulation's goal is to ensure that students in 2045 will be Indonesia's golden generation ${ }^{37}$.

Character education is divided into three components, according to Thomas Lickona:

Character education has three aspects: First, it is the moral knowing. There are six aspects that become the orientation of moral knowing, such as: (1) moral awareness; (2) knowledge of moral values (knowing moral values); (3) taking perspective; (4) providing moral reasoning; (5) making decisions; and (6) making knowledge as their own (selfknowledge). Second, it is the feeling about moral (moral feeling). There are six aspects that become the orientation of the moral feeling, including: (1) conscience; (2) self-esteem; (3) empathy; (4) loving virtue; (5) self-control; and (6) humility. Third, it is the moral actions. There are three aspects that become indicators of moral action, namely: (1) competence; (2) will; and (3) habit38.

The development of a character's values is distributed to the derivatives of its values. This needs a new paradigm in the form of a holistic-integrative and interconnected character ${ }^{39}$. Moral understanding, moral feelings, modesty, and repentance (takhalli, tahalli, and tajalli) are examples of religious character and love for the country that need habituation. Integrity (honesty-trust), love, responsibility, modesty, respect, social concern, tolerance, love of science, patience, hard effort,

Pandemic on Information Management Research and Practice: Editorial Perspectives (December 1, 2020): 102184.

34 Syaifulloh Yusuf et al., Eksistensi Pendidikan Islam (Basis Nilai, Perspektif, dan Inovasi Pengembangannya), I. (Yogyakarta: CV. ISTANA AGENCY, 2020), 143.

35 Syaifulloh Yusuf et al., "Menegosiasikan Islam, Keindonesiaan Dan Mondialitas," I. (Yogayakarta: CV. ISTANA AGENCY, 2021), 141, accessed May 11, 2021, https://dspace.uii.ac.id/handle/123456789/28290.

${ }^{36}$ Deivana Ima, Nanda Restu, and Syaifulloh Yusuf, "Nilai-nilai pendidikan karakter R.A Kartini dalam buku habis gelap terbitlah terang," At-thullab Jurnal Mahasiswa Studi Islam 2, no. 1 (September 14, 2020): 353.

37 "Perpres_Nomor_87_Tahun_2017.Pdf," 4.

${ }^{38}$ C. Arumsari, N. Hudha A, and F. N. Isti'adah, "The Ideal Character of Students Based on Moral Values in Short Movie Videos," Journal of Physics: Conference Series 1179 (July 2019): 3.

${ }^{9}$ Maragustam Maragustam, "Paradigma Holistik-Integratif-Interkonektif Dalam Filsafat Manajemen Pendidikan Karakter," Jurnal Studi Agama dan Masyarakat 11, no. 1 (2015): 122. 
independence, and social interactions are all created by these principles ${ }^{40}$. In the age of mental revolution, character building involves six stages: (1) habituation-cultivation, (2) moral knowledge, (3) moral love and feelings, (4) moral acting, (5) exemplary, and (6) conversion to execute takhalli, tahalli, and tajalliti.

\section{F. The Challenge of Islamic Education in Indonesia in the Era of Disruption}

1. The Challenges of Islamic Education in the Field of Education Technology

The modern age is characterized by the utilization of information technology in the form of smartphone devices for educational purposes. The importance of excellent values in the learning process cannot be denied in Islamic education. Today's problem is that online learning can be done for any subject. In the meanwhile, students must be assessed directly on their attitudes. Direct interactions between teachers and students are still required for students to imitate the teacher's exemplary approach ${ }^{42}$.

2. The Challenges of Islamic Education in the Dichotomy of Science

The dichotomy of science is the dilemma or difficulty of Islamic education. Separation and compartmentalization of religion and general science still exist. Meanwhile, religious knowledge will not function properly in today's modern world without the assistance of advanced educational technologies 43 . Separation of knowledge, both general and religious science, will cause communication issues and conflicts. The challenge of Islamic education is that all knowledge will be more difficult if separated because the essence of each other is mutually reinforcing.

3. The Challenge of Islamic Education in the Education Assessment

In Islamic education, educational assessment is an important component in determining how far the learning process has progressed. Without a precise educational assessment, it will be difficult to properly shape the character of students. In this era of disruption, the challenge of Islamic education is still finding a pattern of evaluation for students depending on the degree of the education unit. Each educational institution, including formal, informal, and non-formal educational institutions, creates its own evaluation methods ${ }^{44}$.

4. The Challenge of Islamic Education in the Material Delivery Process

Many teachers do not deliver material to students more creatively and innovatively. According to Totok Suprayitno, the challenge of the disruptive period is that if a teacher presents content in a mediocre manner, which means that it is no

40 Maragustam Maragustam, "Strategi Pembentukan Karakter Spiritualitas Keagamaan Dan Cinta Tanah Air Dalam Perspektif Filsafat Pendidikan Islam," DAYAH: Journal of Islamic Education 4, no. 1 (January 6, 2021): 1.

${ }^{41}$ Maragustam Maragustam, “Paradigma Revolusi Mental dalam Pembentukan Karakter Bangsa Berbasis Sinergitas Islam dan Filsafat Pendidikan," Jurnal Pendidikan Agama Islam 12, no. 2 (December 2, 2015): 161.

42 Suparlan Suparlan and Sutama Sutama, "Arah Politik Pendidikan Islam di Masa Disrupsi," Paedagoria: Jurnal Kajian, Penelitian dan Pengembangan Kependidikan 11, no. 3 (September 4, 2020): 257.

43 hidayat, "Peran dan Tantangan Pendidikan Agama Islam di Era Global," 138.

44 Kompas Cyber Media, “3 Tantangan Pendidikan Era Disrupsi Teknologi, Apa Saja? Halaman all," KOMPAS.com, last modified September 3, 2019, accessed June 9, 2021, https:/ / edukasi.kompas.com/read/2019/09/03/15390441/3-tantangan-pendidikan-eradisrupsi-teknologi-apa-saja. 
different from a technological machine ${ }^{45}$. This task becomes a whip for all teachers, who must be able to make their own uniqueness in conveying subject matter with advanced technology. The subject material is available from a variety of technological sources, but educators must provide additional instruction in attitude and conscience from themselves.

5. The Challenge of Islamic Education Geographically

In Indonesia, the condition of Islamic education is still unevenly dispersed across the country. Lack of teaching resources in remote areas is a challenge for Islamic educational institutions in the era of disruption ${ }^{46}$. The uneven distribution of teaching resources in various locations has resulted in a disparity in Islamic education knowledge.

\section{G. The Role of Islamic Education in Indonesia in the Disruptive Era}

The development of emotional ${ }^{47}$ and spiritual intelligence is fostered by Islamic education. To promote excellent attitudes and character in students, an exemplary attitude must be emphasized in Islamic education. Today, the teacher's responsibility in setting an example must be displayed, such as worshiping mahdhah and ghairu mahdhah throughout both study and social events. Respect for others, religious attitudes, caring attitudes for friends, caring for the environment, and other daily attitudes are always imparted in the school atmosphere.

One of the aims of education is to help students minimize their stupidity and enhance their intellect. Islamic education has the ability to quell stupidity. The number of educated people must rise, while the number of ignorant people must decrease and finally vanish. Students will be more effective and efficient in achieving a higher quality of life as an outcome of the Islamic education process. Islamic education transforms students' personalities to make them outstanding and ready for community life.

In the learning process of Islamic education, a modern approach must be applied ${ }^{48}$. The importance of Islamic education in upholding Islamic principles and noble character must be highlighted. Noble character and the process of character development are at the core of Islamic education. As a result, its importance can be demonstrated in the maintenance of Islamic principles, which are best promoted by students.

\section{H. Conclusion}

Islamic education in Indonesia during disruption era has several challenges, including the challenges of Islamic education in the face of sophisticated technology, the dichotomy of science, educational assessment (assessment), delivery of material, and geographical location. The purpose of Islamic education in Indonesia at this period

45 Ibid.

46 “Tantangan Disrupsi Teknologi Indonesia," Direktorat Jenderal Pendidikan Tinggi Kementerian Pendidikan Dan Kebudayaan Republik Indonesia, last modified June 22, 2020, accessed June 9, 2021, https://dikti.kemdikbud.go.id/highlight/tantangan-disrupsi-teknologiindonesia/.

47 Ibid., 144.

48 “Tantangan Pendidikan Islam Di Era Disrupsi," Www.Blamakassar.Kemenag.Go.Id, accessed June 9, 2021, http:/ / www.blamakassar.kemenag.go.id/berita/tantangan-pendidikanislam-di-era-disrupsi. 
of upheaval is to preserve Islamic principles and noble character. Islamic education also plays a role in upholding moral standards. The major theories of Thomas Lickona's character education, moral knowing, moral feeling, and moral action, are carried out in connection with sophisticated technology. Islamic education relies on collaboration among educational institutions, parents, and the community. The role of Ki Hajar Dewantara's notion, "Ing Ngarso Sung Tulodo, Ing Madya Mangun Karsa, Tut Wuri Handayani," is carried out as an educational assessment for exemplary attitudes. Thus, the role of the power of Islamic education in the era of disruption in Indonesia can overcome the meaning of the challenge posed by the presence of technology.

\section{REFERENCES}

Abdullah, Muhammad Amin. Multidisiplin, Interdisiplin, E Transdisiplin (Metode Studi Agama \& Studi Islam Di Era Kontemporer). III. Yogyakarta: IB Pustaka, 2021.

Alqudah, Noor M., Hisham M Jammal, Omar Saleh, Yousef Khader, Nail Obeidat, and Jumana Alqudah. "Perception and Experience of Academic Jordanian Ophthalmologists with E-Learning for Undergraduate Course during the COVID-19 Pandemic." Annals of Medicine and Surgery 59 (November 1, 2020): 4447.

Alshawabkeh, Abdallah A., M. Lynn Woolsey, and Faten F. Kharbat. “Using Online Information Technology for Deaf Students during COVID-19: A Closer Look from Experience." Heliyon 7, no. 5 (May 1, 2021): e06915.

Arumsari, C., N. Hudha A, and F. N. Isti'adah. "The Ideal Character of Students Based on Moral Values in Short Movie Videos." Journal of Physics: Conference Series 1179 (July 2019): 012097.

Astuti, Sri, Puri Pramudiani, Khusniyati Masykuroh, and Syafika Ulfah. “Sinergitas Guru dan Orangtua dalam Integrasi Nilai Karakter pada Pembelajaran Daring di Pandemi Covid-19." Jurnal Pendidikan Karakter 0, no. 1 (April 27, 2021). Accessed May 10, 2021. https://journal.uny.ac.id/index.php/jpka/article/view/38898.

Atmaja, Fajar Fandi, and Syaifulloh Yusuf. "Model Pendampingan Manajemen Masjid Ramah Anak Dan Aman Covid-19 Di Masjid Al-Musthofa Dusun Jaten, Sendangadi, Mlati, Sleman." Yumary: Jurnal Pengabdian kepada Masyarakat 1, no. 3 (March 29, 2021): 143-150.

Azanella, Luthfia Ayu. "Empat Varian Baru Virus Corona Masuk Indonesia." KOMPAS.com. Last modified May 7, 2021. Accessed May 9, 2021. https://www.kompas.com/tren/read/2021/05/07/140000765/empat-varianbaru-virus-corona-masuk-indonesia-di-mana-saja-kasusnya-.

Azma, Fereydoon. "The Quality Indicators of Information Technology in Higher Education." Procedia - Social and Behavioral Sciences 30. 2nd World Conference on Psychology, Counselling and Guidance - 2011 (January 1, 2011): 2535-2537.

Doyle, Ronan, and Kieran Conboy. "The Role of IS in the Covid-19 Pandemic: A Liquid-Modern Perspective." International Journal of Information Management 55. Impact of COVID-19 Pandemic on Information Management Research and Practice: Editorial Perspectives (December 1, 2020): 102184.

Elzainy, Ahmed, Abir El Sadik, and Waleed Al Abdulmonem. "Experience of ELearning and Online Assessment during the COVID-19 Pandemic at the College of Medicine, Qassim University." Journal of Taibah University Medical Sciences 15, no. 6 (December 1, 2020): 456-462. 
Hanafi, Yusuf, Ahmad Taufiq, Muhammad Saefi, M. Alifudin Ikhsan, Tsania Nur Diyana, Titis Thoriquttyas, and Faris Khoirul Anam. "The New Identity of Indonesian Islamic Boarding Schools in the 'New Normal': The Education Leadership Response to COVID-19." Heliyon 7, no. 3 (March 1, 2021): e06549.

Haningsih, Sri, Moh Mizan Habibi, Syaifulloh Yusuf, and Fajar Fandi Atmaja. Buku Panduan MKWU Pendidikan Agama Islam Untuk Program Sarjana (S1). I. Yogyakarta: Universitas Islam Indonesia, 2021. Accessed May 11, 2021. https://dspace.uii.ac.id/handle/123456789/27629.

Hidayat, Nur. "Peran dan Tantangan Pendidikan Agama Islam di Era Global." EL TARBAWI 8, no. 2 (2015): 131-145.

Ibrahim, Nahla Khamis, Rajaa Al Raddadi, Moroj AlDarmasi, Abdullah Al Ghamdi, Mahmoud Gaddoury, Hussain M. AlBar, and Iman Kamal Ramadan. "Medical Students' Acceptance and Perceptions of e-Learning during the Covid-19 Closure Time in King Abdulaziz University, Jeddah." Journal of Infection and Public Health 14, no. 1 (January 1, 2021): 17-23.

Ihwanto, Muhammad Arif, Anwar Sutoyo, and Sudarmin Sudarmin. "Desain Pendidikan Karakter Berbasis Nilai-Nilai Ihsan Bagi Siswa MI NU Salafiyah Kudus." Innovative Journal of Curriculum and Educational Technology 6, no. 1 (July 22, 2017): 1-10.

Ima, Deivana, Nanda Restu, and Syaifulloh Yusuf. "Nilai-nilai pendidikan karakter R.A Kartini dalam buku habis gelap terbitlah terang." At-thullab Jurnal Mahasiswa Studi Islam 2, no. 1 (September 14, 2020): 343-354.

Khan, Abdul Gaffar, Md. Kamruzzaman, Md. Nannur Rahman, Monowar Mahmood, and Md. Aftab Uddin. "Quality of Life in the COVID-19 Outbreak: Influence of Psychological Distress, Government Strategies, Social Distancing, and Emotional Recovery." Heliyon 7, no. 3 (March 1, 2021): e06407.

Maragustam, Maragustam. "Paradigma Holistik-Integratif-Interkonektif Dalam Filsafat Manajemen Pendidikan Karakter." Jurnal Studi Agama dan Masyarakat 11, no. 1 (2015): 122-144.

- - - . "Paradigma Revolusi Mental dalam Pembentukan Karakter Bangsa Berbasis Sinergitas Islam dan Filsafat Pendidikan." Jurnal Pendidikan Agama Islam 12, no. 2 (December 2, 2015): 161-175.

- - - "Strategi Pembentukan Karakter Spiritualitas Keagamaan Dan Cinta Tanah Air Dalam Perspektif Filsafat Pendidikan Islam." DAYAH: Journal of Islamic Education 4, no. 1 (January 6, 2021): 1-22.

Marzo, Roy Rillera, Zaliha Ismail, Mila Nu Nu Htay, Rafidah Bahari, Roshidi Ismail, Emilio Quilatan Villanueva, Akansha Singh, et al. "Psychological Distress during Pandemic Covid-19 among Adult General Population: Result across 13 Countries." Clinical Epidemiology and Global Health 10 (April 1, 2021): 100708.

Media, Kompas Cyber. "3 Tantangan Pendidikan Era Disrupsi Teknologi, Apa Saja? Halaman all." KOMPAS.com. Last modified September 3, 2019. Accessed June 9, 2021. https://edukasi.kompas.com/read/2019/09/03/15390441/3-tantanganpendidikan-era-disrupsi-teknologi-apa-saja.

Mei-Ju, Chou, Yang Chen-Hsin, and Huang Pin-Chen. "The Beauty of Character Education on Preschool Children's Parent-Child Relationship." Procedia - Social and Behavioral Sciences 143. 3rd Cyprus International Conference on Educational Research, CY-ICER 2014, 30 January - 1 February 2014, Lefkosa, North Cyprus (August 14, 2014): 527-533. 
Nazula, Lailati, and Erni Munastiwi. "Penguatan Karakter Anak dalam Keluarga dalam Situasi Pandemi Covid-19." Jurnal Pendidikan Karakter 0, no. 1 (April 27, 2021). Accessed May 10, 2021. https://journal.uny.ac.id/index.php/jpka/article/view/37648.

Purvis, Alison J., Helen M. Rodger, and Sue Beckingham. "Experiences and Perspectives of Social Media in Learning and Teaching in Higher Education." International Journal of Educational Research Open 1 (January 1, 2020): 100018.

Rokhman, Fathur, M. Hum, Ahmad Syaifudin, and Yuliati. "Character Education for Golden Generation 2045 (National Character Building for Indonesian Golden Years)." Procedia - Social and Behavioral Sciences 141. 4th World Conference on Learning Teaching and Educational Leadership (WCLTA-2013) (August 25, 2014): 1161-1165.

Romadhon, Muh. Syaiful, Amalia Rahmah, and Yekti Wirani. "Blended Learning System Using Social Media for College Student: A Case of Tahsin Education." Procedia Computer Science 161. The Fifth Information Systems International Conference, 23-24 July 2019, Surabaya, Indonesia (January 1, 2019): 160-167.

Shaw, Rajib, Yong-kyun Kim, and Jinling Hua. "Governance, Technology and Citizen Behavior in Pandemic: Lessons from COVID-19 in East Asia." Progress in Disaster Science 6 (April 1, 2020): 100090.

Silanoi, Ladda. "The Development of Teaching Pattern for Promoting the Building up of Character Education Based on Sufficiency Economy Philosophy in Thailand." Procedia - Social and Behavioral Sciences 69. International Conference on Education \& Educational Psychology (ICEEPSY 2012) (December 24, 2012): 1812-1816.

Skare, Marinko, and Domingo Riberio Soriano. "How Globalization Is Changing Digital Technology Adoption: An International Perspective." Journal of Innovation $\mathcal{E} \quad K n o w l e d g e$ (April 22, 2021). Accessed May 8, 2021. https://www.sciencedirect.com/science/article/pii/S2444569X21000202.

Suparlan, Suparlan, and Sutama Sutama. "ARAH POLITIK PENDIDIKAN ISLAM DI MASA DISRUPSI." Paedagoria: Jurnal Kajian, Penelitian dan Pengembangan Kependidikan 11, no. 3 (September 4, 2020): 257-272.

Ülger, Mehmet, Süleyman Yiğittir, and Orhan Ercan. "Secondary School Teachers' Beliefs on Character Education Competency." Procedia - Social and Behavioral Sciences 131. 3rd World Conference on Educational Technology Researches 2013, WCETR 2013, 7-9 November 2013, Antalya, Turkey (May 15, 2014): 442-449.

Xie, Xuefang, Zhipeng Zang, and José M. Ponzoa. “The Information Impact of Network Media, the Psychological Reaction to the COVID-19 Pandemic, and Online Knowledge Acquisition: Evidence from Chinese College Students." Journal of Innovation \& Knowledge 5, no. 4 (October 1, 2020): 297-305.

Yusuf, Syaifulloh. "Konsep pendidikan akhlak syeikh muhammad syakir dalam menjawab tantangan pendidikan era digital." TA'DIBUNA: Jurnal Pendidikan Agama Islam 2, no. 1 (May 21, 2019): 1-18.

- - - . Manajemen Peserta Didik Untuk Program Sarjana (S1). I. Yogyakarta: Universitas Islam Indonesia, 2021. Accessed May 11, 2021. https://dspace.uii.ac.id/handle/123456789/27628.

Yusuf, Syaifulloh, Sri Haningsih, Moh Mizan Habibi, Supriyanto Abdi, Nanang Nuryanta, Burhan Nudin, Kurniawan Dwi Saputra, et al. "Menegosiasikan Islam, Keindonesiaan Dan Mondialitas." I. Yogayakarta: CV. ISTANA AGENCY, 2021. Accessed May 11, 2021. https:// dspace.uii.ac.id/handle/123456789/28290. 
Yusuf, Syaifulloh, and Kurniawan Dwi Saputra. "Ihsan-Based Character Education." 207-211. Atlantis Press, 2021. Accessed May 10, 2021. https://www.atlantispress.com/proceedings/seaafsid-18/125953604.

Yusuf, Syaifulloh, Ahmad Zubaidi, M Nurul Ikhsan Saleh, Ahmad Darmadji, Moh Mizan Habibi, Edi Safitri, Lukman, et al. Eksistensi Pendidikan Islam (Basis Nilai, Perspektif, dan Inovasi Pengembangannya). I. Yogyakarta: CV. ISTANA AGENCY, 2020.

Zubayer, Abdullah Al, Md. Estiar Rahman, Md. Bulbul Islam, Sritha Zith Dey Babu, Quazi Maksudur Rahman, Md. Rifat Al Mazid Bhuiyan, Md. Kamrul Ahsan Khan, Md Ashraf Uddin Chowdhury, Liakat Hossain, and Rahat Bin Habib. "Psychological States of Bangladeshi People Four Months after the COVID-19 Pandemic: An Online Survey." Heliyon 6, no. 9 (September 1, 2020): e05057.

"Perpres_Nomor_87_Tahun_2017.Pdf," n.d. Accessed May 7, 2021. https://setkab.go.id/wpcontent/uploads/2017/09/Perpres_Nomor_87_Tahun_2017.pdf.

"Tantangan Disrupsi Teknologi Indonesia." Direktorat Jenderal Pendidikan Tinggi Kementerian Pendidikan Dan Kebudayaan Republik Indonesia. Last modified June 22, 2020. Accessed June 9, 2021. https:// dikti.kemdikbud.go.id/highlight/tantangan-disrupsi-teknologiindonesia/.

“Tantangan Pendidikan Islam Di Era Disrupsi." Www.Blamakassar.Kemenag.Go.Id. Accessed June 9, 2021. http:/ / www.blamakassar.kemenag.go.id/berita/tantangan-pendidikan-islamdi-era-disrupsi. 
120 AKADEMIKA: Jurnal Pemikiran Islam

Vol. 26, No. 01 Januari - Juni 2021 